\title{
Hadapi pandemi covid-19 dengan perilaku hidup bersih dan sehat (PHBS) di era new normal
}

\section{Recta Olivia Umboro ${ }^{1 *}$, Fitri Apriliany², Vera Fitriya Ersalena ${ }^{3}$}

\footnotetext{
${ }^{1}$ Universitas Bumigora, Indonesia, email: recta@universitasbumigora.ac.id

2Universitas Bumigora, Indonesia, email: fitriapriliany@universitasbumigora.ac.id

${ }^{3}$ Universitas Bumigora, Indonesia, email:vf.ersalena@universitasbumigora.ac.id

*Koresponden penulis
}

\section{Info Artikel}

Diajukan: 13 Feb 2021

Diterima: 23 Jul 2021

Diterbitkan: 01 Agst 2021

Keywords:

SARS-CoV-2; covid-19; healthy life; hand sanitizer

Kata Kunci:

SARS-CoV-2; covid-19; hidup sehat; hand sanitizer

Lisensi:

cc-by-sa

\begin{abstract}
Severe Acute Respiratory Syndrome Coronavirus 2 (SARS-CoV-2) is a new type of coronavirus that can be transmitted to humans. The government of West Nusa Tenggara Province confirmed 3.082 positive cases of Covid-19 with 223 cases in Central Lombok by September 2020. Geographically, Penujak is one of villages in Central Lombok close to Lombok International Airport which is an entry point for local and international tourists. Thus, Lecturers of Division of Pharmacy, Bumigora University conducted Community Service Activity entitled "Sosialisasi Hidup Sehat dan Bersih di Tengah Pandemi Covid-19 dan Pelatihan Pembuatan Hand Sanitizer" which aims to educate societies how to start healthy life. The community service was done by socializing for healthy living and adapting to the new normal, and training to formulating hand sanitizer properly. Therefore, new insights and better understanding were gained in order to live healthily and to implement their skills to produce proper standar for hand sanitizer.
\end{abstract}

Abstrak
Severe Acute Respiratory Syndrome Coronavirus 2 (SARS-CoV-2)
merupakan jenis baru coronavirus yang dapat menular ke manusia.
Pemerintah Provins/ Nusa Tenggara Barat mengkonfirmasi 3.082
kasus positif Covid-19 dengan 223 kasus di Lombok Tengah. Secara
geografis, Penunjak adalah salah satu desa di Lombok Tengah
dimana cukup dekat dengan Bandara Internasional Lombok yang
menjadi pintu masuk bagi wisatawan lokal maupun internasional.
Kawasan ini cukup beresiko sebagai kawasan penularan Covid-19,
sehingga Tim Dosen Program Studi Farmasi, Universitas Bumigora
melaksanakan Pengabdian Masyarakat dengan tema "Sosialisasi
Hidup Sehat dan Bersih di Tengah Pandemi Covid-19 dan Pelatihan
Pembuatan Hand Sanitizer" yang bertujuan untuk mengedukasi
masyarakat agar selalu menerapkan hidup sehat dan bersih. Kegiatan
ini dilaksanakan selama tiga hari dengan memberikan sosialisasi
hidup sehat dan adaptasi kebiasaan baru, dan pelatihan pembuatan
hand sanitizer. Dari kegiatan ini, masyarakat dapat
mengimplementasikan perilaku hidup sehat dan bersih di tengah
pandemi, dan keterampilan membuat hand sanitizer dengan formula
yang sesuai dengan standar.




\section{PENDAHULUAN}

Severe Acute Respiratory Syndrome Coronavirus 2 (SARS-CoV-2) yang lebih dikenal dengan nama virus corona adalah jenis baru dari corona virus yang menular ke manusia. Virus ini bisa menyerang siapa saja, seperti lansia (golongan usia lanjut), orang dewasa, anak-anak, dan bayi, termasuk ibu hamil dan ibu menyusui. Infeksi virus corona atau yang biasa disebut Covid-19 (Corona Virus Disease 2019) dan pertama kali ditemukan di kota Wuhan, China pada akhir Desember 2019. Virus ini menular dengan sangat cepat dan telah menyebar ke hampir semua negara, termasuk Indonesia hanya dalam waktu beberapa bulan (W H O, 2020).

Kementerian Kesehatan (Kemenkes) secara umum mengemukakan bahwa Covid-19 merupakan keluarga besar dari virus yang menyebabkan penyakit ringan sampai berat, seperti common cold atau pilek dan penyakit yang serius seperti MERS dan SARS (Yurianto, 2020). Perilaku/karakteristik baru pada Covid-19 ini adalah kemampuannya menginfeksi dan menular dari manusia ke manusia dengan cepat, dapat mengakibatkan penderita radang paru pneumonia, sesak nafas, dan kematian. Mencermati penyebaran dan penularan Covid-19 di Indonesia yang semakin memprihatinkan, Pemerintah melalui Keputusan Presiden Nomor 11 Tahun 2020 telah menetapkan Kedaruratan Kesehatan Masyarakat Covid-19 di Indonesia yang mewajibkan dilakukan upaya penanggulangan sesuai dengan ketentuan peraturan perundang-undangan. Tindakan pencegahan yang dilakukan melalui mekanisme physical distancing, social distancing, pengadaan Alat Pelindung Diri (APD), sampai pada Pembatasan Sosial Berskala Besar (PSBB) (Silalahi, 2020; Widiastuti, 2020).

Penyebaran Covid-19 mulai menjadi topik nasional terjadi di awal bulan Maret 2020 tepatnya di kota-kota yang berada di pulau Jawa terutama Jakarta, Jawa Barat dan Jawa Timur. Sejak awal terkonfirmasi jumlah pasien yang terinfeksi Covid-19 terus mengalami peningkatan yang signifikan. Pertanggal 20 September 2020, jumlah angka pasien positif Covid-19 yang terkonfirmasi berjumlah 244.676 kasus (Satuan Tugas Penanganan Covid-19, 2020).

Lombok Tengah merupakan salah satu wilayah yang berada di Provinsi Nusa Tenggara Barat (NTB). Wilayah ini menjadi salah satu wilayah yang menjadi fokus pengawasan dalam upaya pencegahan penularan Covid-19. Hal ini dikarenakan di wilayah Lombok Tengah terdapat Bandara Internasional Zainuddin Abdul Madjid yang merupakan salah satu pintu masuk bagi pendatang ataupun wisatawan baik dari dalam negeri maupun luar negeri. Selain itu di wilayah Lombok Tengah terdapat ikon-ikon tempat wisata yang bisa menjadi pusat penularan Covid-19. Angka kejadian positif Covid-19 di daerah Lombok Tengah menurut data yang diperoleh dari laman Covid-19 NTB milik Pemerintah Daerah NTB mulai terkonfirmasi sejak tanggal 19 April 2020 yaitu sebanyak 6 kasus positif. Menurut data yang diperoleh dari laman Covid-19 NTB jumlah total kasus positif terkonfirmasi di wilayah Lombok Tengah sampai dengan pertanggal 9 September 2020 sebanyak 223 kasus dengan penambahan 1 pasien terkonfirmasi positif (Diskominfotik NTB, 2021; Lalu, 2020). 
Penunjak merupakan salah satu desa yang berada di wilayah Praya Barat Kabupaten Lombok Tengah. Sebagian besar mata pencarian penduduk di desa ini adalah bertani dimusim tertentu. Berdasarkan letak geografisnya, Penunjak memiliki risiko cukup besar menjadi wilayah penularan Covid-19.

Melihat fenomena angka kejadian Covid-19 yang terus bertambah sampai dengan hari ini serta semakin abainya masyarakat untuk tetap menjalankan protokol kesehatan dalam beraktivitas, kami dari tim Pengabdian Kepada Masyarakat (PKM) Program Studi Farmasi Fakultas Kesehatan Universitas Bumigora bekerja sama dengan Perangkat Desa, Ketua PKK dan Kader Posyandu melakukan kegiatan yang bertujuan untuk mengingatkan masyarakat bahwa Covid-19 masih ada di tengah kita dan mereedukasi masyarakat khususnya di Desa Penunjak Kabupaten Lombok Tengah terkait Covid-19, bagaimana menjalankan protokol kesehatan yang baik dan benar dalam beraktivitas sehari-hari, sehingga kesadaran masyarakat dalam menjalankan protokol kesehatan dapat terus dijaga dan ditingkatkan dimasa pandemi Covid-19 yang masih terus berlangsung.

Selain bertujuan untuk mereedukasi agar masyarakat tidak lalai dalam menerapkan PHBS dan protokol kesehatan dalam beraktivitas, kegiatan PKM ini juga bertujuan untuk memberikan keterampilan kepada masyarakat dalam membuat sediaan farmasi (hand sanitizer dan disinfectant) sesuai standar WHO menggunakan alat, bahan yang mudah didapat dan terjangkau dengan tetap memperhatikan cara formulasi menurut standar compounding yang baik dan benar.

Upaya pemerintah dalam menekan penyebaran Covid-19 adalah dengan Adaptasi Kebiasaan Baru (AKB) atau yang lebih dikenal new normal. Mekanisme AKB ini adalah dengan menerapkan protokol kesehatan dalam beraktivitas sehari-hari dengan melakukan gerakan masyarakat untuk menjaga jarak, menggunakan masker, mencuci tangan. Penanganan dan pencegahan angka penularan Covid-19 dapat ditekan dengan menerapkan perilaku sosial yang baik (Van Bavel et al., 2020). Menerapkan budaya hidup bersih dan sehat sangatlah penting dan diperlukan dalam menghadapi pandemi Covid-19 yang berkepanjangan (Apriliany et al., 2021).

Perilaku hidup bersih dan sehat yang penting untuk dilakukan adalah menjaga kebersihan diri dan lingkungan. Menjaga kebersihan diri salah satunya dengan menjaga kebersihan tangan. Seperti yang kita ketahui tangan merupakan media perantara dimana Covid-19 dapat ditularkan. Menjaga kebersihan tangan selain dengan mencuci menggunakan sabun, dapat dilakukan dengan menggunakan hand sanitizer. Hand sanitizer yaitu sebuah produk yang memiliki kandungan antiseptik sebagai pembersih tangan, dimana penggunaannya tidak perlu dibilas dengan air. Menurut Food and Drug Administration (FDA), hand-sanitizer bisa membunuh kuman dalam waktu kurang dari 30 detik (Nakoe et al., 2020).

Penggunaan hand sanitizer lebih efisien bila dibandingkan mencuci tangan dengan sabun dan air, sehingga masyarakat lebih tertarik untuk menggunakannya. Hand sanitizer ada yang berbentuk cair ataupun gel, namun masyarakat umumnya menyukai penggunaan hand sanitizer dalam bentuk gel, 
yang dapat menimbulkan rasa dingin di kulit, mudah kering dan dapat membunuh bakteri dalam waktu yang relatif singkat, karena mengandung senyawa alkohol dan golongan fenol. Mekanisme kerja dari kedua senyawa tersebut adalah dengan mendenaturasi dan mengkoagulasi protein sel kuman (Asngad \& R, 2018).

Manusia sebagai salah satu sumber transmisi penyebaran Covid-19, dimana penyebaran utama virus ini melalui tetesan atau droplet akibat berbicara, batuk atau bersin. Tetesan atau droplet yang mengandung virus dapat bertahan lama di udara dan menempel pada benda-benda di sekitar lingkungan tempat kita berada. Salah satu cara untuk menjaga lingkungan tetap bersih adalah dengan memanfaatkan cairan disinfectant. Disinfectant merupakan zat yang dapat membunuh patogen di lingkungan. Disinfectant biasanya mengandung glutaraldehid dan formaldehid. Penggunaan zat-zat tersebut sebelumnya lebih menjadi tanggung jawab tenaga medis, namun dimasa pandemi Covid-19 seperti sekarang penggunaan disinfectant menjadi lebih umum (Suryandari \& Saqif Haidarravy, 2020).

Dalam menghadapi pandemi yang berkepanjangan, banyak hal yang harus diketahui, dipahami dan dilakukan oleh masyarakat. Untuk itu perlu dilakukan edukasi kepada masyarakat agar mau membiasakan diri menjalani PHBS diera new normal serta memberikan keterampilan kepada masyarakat terkait cara pembutan hand sanitizer dan disinfectant yang benar, karena tingginya pengetahuan dan kesadaran masyarakat terkait pandemi dapat menekan laju penyebaran Covid-19 (Astuti et al., 2020). Semakin dini pembiasaan hidup sehat dilakukan, semakin tinggi pula derajat kesehatan masyarakat karena upaya preventif tersebut (Imam Rofiki \& Siti Roziah Ria Famuji, 2020).

\section{METODE PELAKSANAAN}

Sasaran pada kegiatan pengabdian ini adalah ibu-ibu dan remaja putri di Desa Penunjak Kecamatan Praya Barat Kabupaten Lombok Tengah NTB. Alokasi waktu untuk pelaksanaan pengabdian dilakukan selama 3 hari. Pelaksanaan kegiatan ini diawali dengan pemilihan lokasi dan berkoordinasi dengan pihak desa/dusun, terkait izin pelaksanaan kegiatan. Kegiatan dilaksanakan di Kantor Kepala Desa Penunjak Kecamatan Praya Barat Kabupaten Lombok Tengah NTB dengan tetap menjalankan protokol kesehatan. Sehingga jumlah peserta yang hadir dibatasi tidak lebih dari 20 orang dan dilakukan dalam 2 hari yaitu pada tanggal 25 dan 26 September 2020.

Metode pelaksanaan program PKM dengan tema "Sosialisasi Hidup Sehat dan Bersih di Tengah Pandemi Covid-19 dan Pelatihan Pembuatan Hand Sanitizer" dilakukan dengan beberapa tahapan antara lain:

1. Sosialisasi Covid-19 dan Adaptasi Kebiasaan Baru (AKB/New Normal)

Pelaksanaan sosialisasi ini dilakukan dengan memberikan edukasi melalui penyuluhan terkait Covid-19 dan AKB/new normal. Penyuluhan ini bertujuan mengedukasi masyarakat terkait penyebab, faktor risiko, cara 
pencegahan dan bagaimana menjalankan protokol kesehatan di tengah pandemi.

2. Dialog interaktif dengan masyarakat terkait Covid-19

Peserta penyuluhan dan pelatihan diberi kesempatan untuk bertanya terkait permasalahan Covid-19 yang belum dipahami, sehingga dari dialog ini dapat mengukur tingkat kepahaman peserta terhadap tema yang diangkat.

3. Pelatihan pembuatan hand sanitizer dan disinfectant oleh tim dosen Program Studi Farmasi, Universitas Bumigora kepada ibu-ibu PKK, Posyandu dan remaja putri di Desa Penunjak

Pelatihan diawali dengan penjelasan umum terkait hand sanitizer dan disinfectant. Selanjutnya tim dosen memaparkan alat, bahan yang digunakan dan mempraktekan langkah-langkah pembuatan hand sanitizer dan disinfectant. Dalam kegiatan pelatihan ini peserta juga diberi kesempatan untuk bertanya terkait tema pelatihan dan mempraktekkan langsung bagaimana cara membuart hand sanitizer dan disinfectant yang baik dan benar.

\section{HASIL DAN PEMBAHASAN}

Kegiatan PKM ini dilaksanakan dalam rangka menyambut hari Farmasis Sedunia yang jatuh pada tanggal 25 September 2020. Kegiatan ini merupakan bentuk kepedulian Program Studi Farmasi Universitas Bumigora terhadap bencana pandemi Covid-19 yang melanda dunia, Indonesia termasuk Provinsi NTB.

Pelaksanaan kegiatan ini diawali dengan survei lokasi dan pengumpulan data terkait total jumlah warga (ibu-ibu dan remaja putri) yang akan hadir melalui Kader Posyandu, Ketua PKK dan Ibu Kepala Desa. Pemilihan kaum ibu dan perempuan sebagai peserta penyuluhan dan pelatihan didasari pada peran wanita sebagai ibu dan orang tua dalam sebuah keluarga memiliki fungsi yang penting sebagai pendamping, pengingat guna menjaga kesehatan bagi anggota keluarganya (Kurniati et al., 2020), dan tidak dapat dipungkiri peran ibu-ibu, remaja putri sebagai kader posyandu dan PKK sangat berguna dalam mengkampanyekan gerakan untuk hidup bersih dan sehat di tengah pandemi yang berkepanjangan (Jaya et al., 2021). Hasil survei yang dilakukan diperoleh data jumlah warga yang menjadi target penyuluhan dan pelatihan kurang lebih 35 orang yang terdiri dari ibu rumah tangga dan remaja putri.

Agar kegiatan berlangsung tertib dan tetap dapat menjalankan protokol kesehatan, pelaksanaan kegiatan dilakukan dalam 2 batch berbeda, yang masing-masing batch dihadiri tidak lebih dari 20 orang peserta dengan jadwal kegiatan selama 2 hari yaitu pada tanggal 25 dan 26 September 2020. Lokasi kegiatan dilaksanakan di kantor Kepala Desa Penunjak, Kecamatan Praya Barat Kabupaten Lombok Tengah. Pemilihan lokasi ini mempertimbangkan kemudahan untuk diakses, dan jarak lokasi dari rumah warga yang tidak terlalu jauh. Selain itu agar selama kegiatan protokol kesehatan benar-benar bisa 
dilaksanakan dengan baik mengingat lokasi ruang pertemuan desa yang cukup luas.

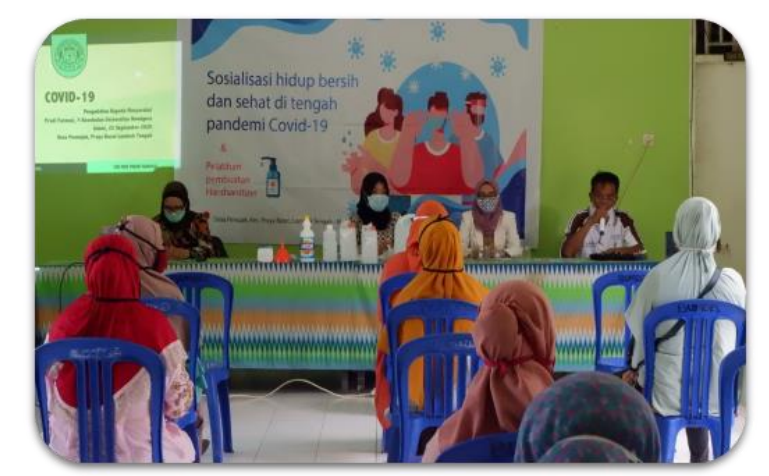

Gambar 1. Penyuluhan Hidup Bersih dan Sehat di Tengah Pandemi

Reedukasi terkait Covid-19, dilakukan dengan memberikan penyuluhan (Gambar 1) yang meliputi tentang: pengetahuan umum virus corona, etiologi Covid-19, patofisiologi Covid-19, epidemiologi Covid-19, pravalensi Covid-19, faktor risiko, tindakan preventif, AKB/New Normal. Edukasi terkait AKB disini menitikberatkan pada pembiasaan untuk menerapkan perilaku hidup bersih dan sehat di tengah pandemi dengan tetap menjalankan protokol kesehatan selama beraktivitas.

Media edukasi yang digunakan dalam kegiatan ini berupa gambar dan video terkait bagaimana etika batuk dan bersin, cara memakai masker yang benar, cara mencuci tangan dan melakukan social atau physical distancing. Penggunaan media gambar dan video dipilih karena merupakan media yang paling efektif dalam menyampaikan informasi terkait pendidikan kesehatan (Mulyadi et al., 2018).

Tujuan dari reedukasi ini dilakukan agar masyarakat tetap waspada terkait kondisi pandemi yang masih berlangsung sehingga sangat penting bagi kita semua untuk selalu menerapkan protokol kesehatan dalam beraktvitas. Selain itu kegiatan ini juga untuk menanamkan stigma di masyarakat bahwa terinfeksi Covid-19 bukanlah aib, sehingga tidak perlu merasa malu. Pemahaman ini penting dan perlu ditanamkan pada masyarakat agar masyarakat lebih peduli dan tidak terjadi perilaku yang mendeskritkan orang yang terinfeksi Covid-19 di lingkungan sekitarnya.

Untuk mengukur tingkat pemahaman terkait Covid-19 dan kebiasaan hidup sehat di tengah pandemi pada kegiatan ini dilakukan dialog interaktif dengan peserta kegiatan. Selama sesi dialog yang dilakukan menunjukkan bahwa masyarakat di Desa Penunjak memiliki kesadaran yang tinggi untuk menjaga kebersihan dan kesehatan di tengah pandemi Covid-19. Hal ini terlihat dari tingginya keingintahuan mereka terkait pencegahan dan penanganan Covid-19 melalui pertanyaan-pertanyaan dan tindakan apa yang harus dilakukan terkait permasalahan tersebut. 


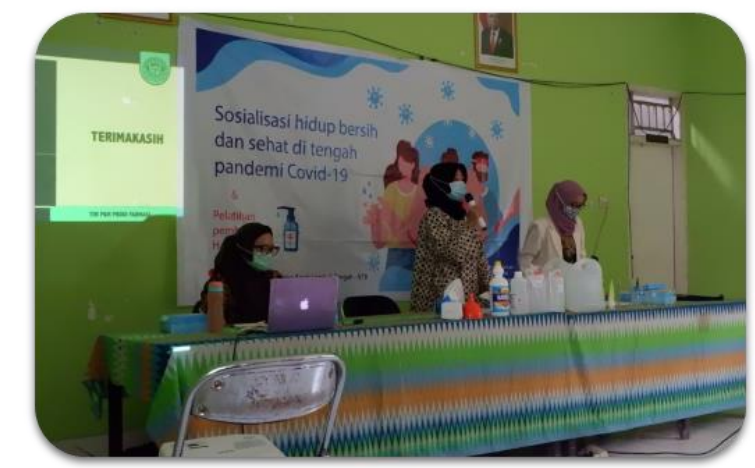

Gambar 2. Pelatihan Pembuatan Hand sanitizer dan Disinfectant

Kegiatan PKM ini juga memberikan keterampilan yang baru bagi masyarakat khususnya ibu-ibu dan remaja putri di Desa Penunjak Praya Barat Kabupaten Lombok Tengah melalui kegiatan pelatihan pembuatan hand sanitizer dan disinfectant (Gambar 2.). Pelatihan ini dilakukan dengan metode pendampingan praktek langsung, dimana masyarakat diberi arahan terkait alat, bahan dan prosedur pembuatan yang selanjutnya masyarakat diberi kesempatan untuk mempraktekkan cara pembuatan secara langsung dengan dibimbing oleh tim dosen farmasi. Produk yang dihasilkan pada kesempatan pelatihan ini dapat dilihat pada Tabel 1.

Tabel 1. Produk Hasil Pelatihan

\begin{tabular}{cccc}
\hline No & Nama Produk & Jumlah & Satuan \\
\hline 1 & Hand sanitizer & 4 & Liter \\
2 & Disinfectant & 3 & Liter \\
\hline
\end{tabular}

Hand sanitizer berdasarkan WHO memiliki kandungan alkohol $96 \%$, gliserin, hidrogen peroksida $\left(\mathrm{H}_{2} \mathrm{O}_{2}\right)$ dan air. Penggunaan alkohol dan hidrogen peroksida semakin besar konsentrasi yang digunakan maka semakin efektif untuk menghambat pertumbuhan bakteri. Tingginya konsentrasi penggunaan bahan kimia tersebut dapat berbahaya bagi kesehatan kulit. Oleh karena itu digunakan bahan alam sebagai inovasi yang berfungsi untuk menghambat pertumbuhan bakteri, sekaligus dapat mengurangi penggunaan bahan kimia dalam produk hand sanitizer (Maulidie et al., 2019). Pada pembuatan hand sanitizer kami menggunakan bahan alam berupa gel lidah buaya yang berfungsi sebagai humektan, sehingga iritasi pada kulit yang disebabkan senyawa alkohol dan fenol dapat dihindari.

Kedua produk hasil pelatihan tersebut diserahkan kepada masyarakat untuk dapat dipergunakan sesuai dengan fungsinya masing-masing. Selanjutnya agar masyarakat bisa mempraktekkan sendiri bagaimana membuat prodak hasil pelatihan di komunitas sosial yang ada di Desa Penunjak, tim PKM Program Studi Farmasi juga menyerahkan bahan berupa alkohol $96 \%$, aloevera gel, aquadest dan cairan pemutih sebagai bahan baku pembuatan hand sanitizer dan disinfectant. 
Masyarakat Desa Penunjak, Praya Barat Kabupaten Lombok Tengah menyambut baik kegiatan ini, karena kegiatan terkait mengedukasi masyarakat di bidang kesehatan sangat jarang dilakukan. Mereka juga berharap kegiatan serupa bisa terus dilakukan tidak hanya selama pandemi Covid-19 saja.

\section{KESIMPULAN}

Pengabdian Kepada Masyarakat (PKM) Program Studi Farmasi Fakultas Kesehatan Universitas Bumigora (UBG) dilakukan di Desa Penunjak, Kecamatan Praya Barat Kabupaten Lombok Tengah dengan Tema Sosialisasi Hidup Sehat dan Bersih di Tengah Pandemi Covid-19 \& Pelatihan Pembuatan Hand Sanitizer merupakan perwujudan pelaksanaan Tridharma perguruan tinggi bidang pengabdian. Kegiatan ini dilaksanakan dalam rangka menyambut Hari Farmasi Sedunia yang jatuh pada tanggal 25 September 2020.

Capain yang bisa dilihat dari pelaksanaan kegiatan ini adalah semakin tingginya pemahaman masyarakat Desa Penunjak akan pentingnya untuk melaksanakan PHBS ditengah pandemi Covid-19. Hal ini ditunjukkan dengan kepedulian masyarakat untuk mencari tahu segala hal yang wajib dan perlu dilakukan untuk menghindari terinfeksi Covid-19, dan cara mengatasi apabila terinfeksi Covid-19.

Kegiatan edukasi terkait bidang kesehatan perlu dan harus ditingkatkan melalui penyuluhan dan pelatihan yang mampu meningkatkan pengetahuan dan pemahaman masyarakat. Pengetahuan tidak dapat dipahami secara menyeluruh bila tidak disertai dengan contoh, sehingga dalam hal penerapan perilaku hidup bersih dan sehat diharapkan dapat memberikan contoh kepada keluarga bahwa menerapkan perilaku hidup bersih dan sehat itu penting baik bagi diri sendiri, orang lain dan lingkungan disekitarnya.

\section{UCAPAN TERIMA KASIH}

Tim Pengabdian Kepada Masyarakat Program Studi Farmasi Universitas Bumigora mengucapakan terima kasih kepada Kepala Desa Penunjak, Praya Barat Kabupaten Lombok Tengah beserta jajarannya yang telah memberikan izin guna terselenggaranya kegiatan dengan tema "Sosialisasi Hidup Bersih dan Sehat di Tengah Pandemi \& Pelatihan Pembuatan Hand Sanitizer".

\section{DAFTAR RUJUKAN}

Apriliany, F., Umboro, R. O., Ersalena, V. F., Farmasi, P., Kesehatan, F., \& Bumigora, U. (2021). Penyuluhan Gema Cermat Obat dan Pelatihan Pembuatan Hand Sanitizer. Jurnal Abdidas, 2(1), 41-47. https://doi.org/10.31004/abdidas.v2i1.207

Asngad, A., \& R, A. B. (2018). Kualitas Gel Pembersih Tangan ( Handsanitizer ) dari Ekstrak Batang Pisang dengan Penambahan Alkohol, Triklosan dan Gliserin yang Berbeda Dosisnya. Bioeksperimen Jurnal Penelitian Biologi, 4(2), 61-70. https://doi.org/10.23917/bioeksperimen.v4i2.6888

Astuti, S. F., Nursyabania, L., Falih, M. J., Attamini, R., Rafli, M., Musta, S., Apoteker, P., Farmasi, F., Kimia, D., \& Sains, F. (2020). Sosialisasi 
Adaptasi Kebiasaan Baru DI RT 5 / RW 11, Kelurahan Pasar Reb, Jakarta Timur Menghadapi Pandemi Covid-19. Jurnal Layanan Masyarakat, 4(2), 448-455. https://doi.org/10.20473/jlm.v4i2.2020.448455

Diskominfotik NTB. (2021). Press Release. https://corona.ntbprov.go.id/pressrelease

Imam Rofiki, \& Siti Roziah Ria Famuji. (2020). Kegiatan Penyuluhan dan Pemeriksaan Kesehatan untuk Membiasakan PHBS bagi Warga Desa Kemantren. Dinamisia: Jurnal Pengabdian Kepada Masyarakat, 4(4), 628-634. https://doi.org/10.31849/dinamisia.v4i4.3992

Jaya, S. T., Wulandari, R. F., \& Susiloningtyas, L. (2021). Pendidikan Kesehatan PHBS Kader Kesehatan Era New Normal di Desa Darungan. Journal of Community Engagement in Health, 4(1), 162-166. https://doi.org/10.30994/jceh.v4i1.131

Kurniati, E., Alfaeni, D. K. N., \& Andriani, F. (2020). Analisis Peran Orang Tua dalam Mendampingi Anak di Masa Pandemi Covid-19. Jurnal Obsesi: Jurnal Pendidikan Anak Usia Dini, 5(1), 241-256. https://doi.org/10.31004/obsesi.v5i1.541

Lalu, G. ariadi. (2020). Press Release Data Covid NTB (Vol. 10, Issue 1, pp. 12).

Maulidie, M., Saputera, A., Widia, T., Marpaung, A., \& Ayuchecaria, N. (2019). Konsentrasi Hambat Minimu (KHM) Kadar Ekstrak Etanol Batang Bajakah Tampala( Spatholobus littoralis Hassk) Terhadap Bakteri Escherichia Coli Melalui Metode Sumuran. Jurnal IImiah Manuntung, 5(2), 167-173. https://doi.org/10.51352/jim.v5i2.267

Mulyadi, M. I., Warjiman, W., \& Chrisnawati, C. (2018). Efektivitas Pendidikan Kesehatan Dengan Media Video Terhadap Tingkat Pengetahuan Perilaku Hidup Bersih Dan Sehat. Jurnal Keperawatan STIKES Suaka Insani (JKSI), 3(2), 1-9. https://doi.org/10.51143/jksi.v3i2.111

Nakoe, M. R., S, N. A., \& Mohamad, Y. A. (2020). Perbedaan Efektifitas HandSanitizer Dengan Cuci Tangan Menggunakan Sabun Sebagai Bentuk Pencegahan COVID-19. Journal of Health Sciences and Research (Jambura), 2(2), 65-70. https://doi.org/10.35971/gojhes.v2i2.5268

Satuan Tugas Penanganan COVID-19. (2020). Analisis Data COVID-19 di Indonesia per 20 September 2020. September.

Silalahi, A. (2020). Perubahan Pola Hidup Pada Situasi Covid-19. Research in Biochemistry, 1-12. https://doi.org/10.13140/RG.2.2.10961.76646

Suryandari, N., \& Saqif Haidarravy. (2020). Pembuatan Cairan Desinfektan dan Bilik Disinfektan sebagai Upaya Pencegahan Virus COVID-19 di Mlajah Bangkalan Madura. Jurnal Abdidas, 1(5), 345-351. https://doi.org/10.31004/abdidas.v1i5.70

Van Bavel, J. J., Baicker, K., Boggio, P. S., Capraro, V., Cichocka, A., Cikara, M., Crockett, M. J., Crum, A. J., Douglas, K. M., \& Druckman, J. N. (2020). Using Social and Behavioural Science To Support COVID-19 Pandemic Response. Nature Human Behaviour, 4(5), 460-471. https://doi.org/10.1038/s41562-020-0884-z 
W H O. (2020). Clinical management of severe acute respiratory infection when novel coronavirus (2019-nCoV) infection is suspected. 1-10.

Widiastuti, N. K. (2020). Adaptasi Kebiasaan Baru Di Masa Pandemi Covid-19. Dinas Kesehatan Provinsi

Bali. https://www.diskes.baliprov.go.id/adaptasi-kebiasaan-baru-di-masapandemi-covid-19/

Yurianto, A. (2020). Pedoman Pencegahan dan Pengendalian Coronavirus Disease (COVID-19). Germas, 0-115. 